\title{
Water Quality Credit Trading: General Principles'
}

\author{
Tara Wade and Tatiana Borisova ${ }^{2}$
}

\section{Introduction}

Protection of the quality of Florida water resources is an important priority for the public and the government agencies (Figure 1). Pollution of surface water (e.g., lakes, rivers, and streams) can be linked to fish kills, changes in the color and aesthetic appeal of the resource, changes in the quality of habitat for aquatic plant and animal life (leading to changes in the plant and animal communities), and to human health issues. To address the pollution problems, a variety of programs is implemented at the federal, state, and local levels. Despite these programs, water quality problems persist. A recent FDEP water quality assessment report shows that the concentration of nitrogen in surface water is increasing in some Florida regions, and most assessed rivers, streams, canals, lakes, and estuaries were not meeting surface water quality standards (FDEP 2016). Although there have been gains in pollution reduction, reducing pollution and improving water quality is still a public policy objective in Florida. Costs to implement Florida's water policy objective will be borne by Florida citizens and businesses. Market-based programs, such as water quality credit trading, can provide environmental benefits at lower costs and more quickly than other policy instruments (Shortle 2013). In this document, we review the basic components of a water quality credit trading program and discuss opportunities and challenges associated with a water quality credit trading program design. Technical terms used in this publication are bolded, and a glossary is available at the end of the document.

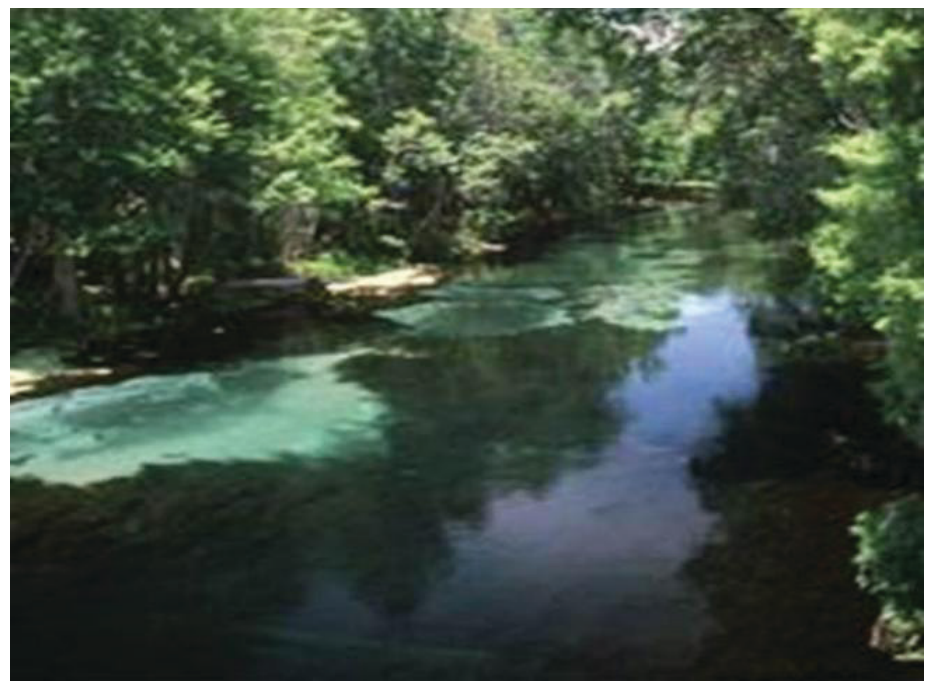

Figure 1.

Credits: Audrey Wynne, UF/IFAS

\section{Water Quality Credit Trading}

Water quality credit trading (WQCT) is being tested in several states as a policy tool to stimulate provisions of clean water. For example, the focus of the California Grassland Area Program is the reduction of selenium water pollution in agricultural areas of the San Joaquin Valley. The focus of the Connecticut Nitrogen Credit Exchange Program is to meet the nitrogen water quality standards for the Connecticut River and to protect the Long Island Sound. The focus of the Pennsylvania Nutrient Credit Trading is the reduction of nutrient (nitrogen and phosphorus) loading from Pennsylvania to the Chesapeake Bay (Shortle

1. This is EDIS document FE824, a publication of the Food and Resource Economics Department, UF/IFAS Extension. Original publication date December 2009 Revised July 2017 and January 2022. Please visit the EDIS website at https://edis.ifas.ufl.edu for the currently supported version of this publication.

2. Tatiana Borisova, assistant professor, Food and Resource Economics Department; and Tara Wade, assistant professor, Food and Resource Economics Department, UF/IFAS Southwest Florida Research and Education Center; UF/IFAS Extension, Gainesville, FL 32611.

The Institute of Food and Agricultural Sciences (IFAS) is an Equal Opportunity Institution authorized to provide research, educational information and other services

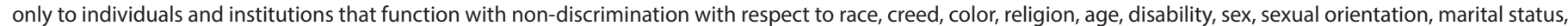

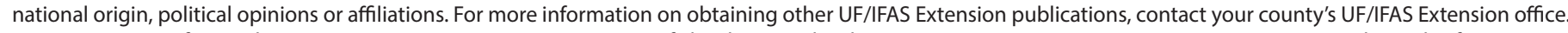
U.S. Department of Agriculture, UF/IFAS Extension Service, University of Florida, IFAS, Florida A \& M University Cooperative Extension Program, and Boards of County Commissioners Cooperating. Andra Johnson, dean for UF/IFAS Extension. 
2013). In Florida, WQCT has become an ongoing project. It was first authorized in 2008 to incentivize nutrient pollution reduction in the Lower St. Johns River Basin. In 2013, Florida House Bill 713 allowed setting up WQCT programs to address water pollution issues throughout the entire state (403.067 Florida Statute).

WQCT programs are designed with the objective to reduce the level of water pollutants, especially nutrients (nitrogen and phosphorus), by letting emitters (pollution sources) in a watershed trade among themselves to find the most costefficient way of reducing pollution (Bennett et al. 2013). WQCT is based on the idea that pollution-control costs differ from source to source. The overall costs of achieving pollution-reduction goals in a watershed are minimized if sources are allowed to reallocate (trade) pollution reductions according to their pollution-abatement costs. The commodity being traded is either a discharge allowance from regulated sources (e.g., wastewater treatment plant) or pollution reduction credits from non-regulated sources (e.g., agriculture or oyster harvesting) (Selman et al. 2009; Greenhalgh and Selman 2017; NCCOS 2017).

In most states, agriculture is included in the non-regulated sources category because pollution runoff from specific agricultural fields is difficult to measure. These sources can voluntarily implement best management practices (BMPs) to address potential pollution problems and improve the efficiency of the use of various inputs (such as fertilizers and water). In Florida, implementing agricultural BMPs is also voluntary with one important exception. If an agricultural operation is in an area where the Florida Department of Environmental Protection (FDEP) documented water quality problems, then the BMP implementation may be mandatory. In turn, industrial and municipal pollution sources (such as municipal wastewater treatment plants) are regulated through permits for emissions.

The advantages of WQCT in comparison with traditional water pollution regulations may include

- allowing individual entities flexibility in choosing pollution-abatement technologies and practices (e.g., flexibility for the farmers to choose which BMPs to implement)

- providing incentives to innovate within the pollutionabatement sphere (e.g., develop and implement new BMPs to offer pollution reduction credits on the market)

- addressing future growth in the basin while meeting water quality goals

To illustrate the mechanics of WQCT, consider a simplified example presented in Tables 1 and 2. Assume that there are two separate entities within a basin: a municipal wastewater treatment plant (MWTP) and a livestock farmer (LF). Each entity discharges water that contributes to phosphorus (P) pollution of a stream. The environmental goal is to reduce $\mathrm{P}$ loadings by two units. We further assume that reducing the $\mathrm{P}$ load from either or both entities has equal value toward achieving the environmental goal. Without trading, the total cost of achieving the pollution reduction target ( 2 units of $P$ reduced) is $\$ 50$. As outlined in Table 1 , each entity works independently to achieve its share of the environmental goal. Total cost of pollution reduction is simply the addition of costs across the two entities.

Now let us consider the possibility that the MWTP and the LF can interact and collaboratively achieve the environmental objective. Since the unit cost to reduce $\mathrm{P}$ loading is less for the LF, the MWTP manager proposes that the entire $P$ reduction (2 units) be accomplished by the LF. The LF is willing to participate so long as the LF financially gains. In effect, the LF sells the MWTP manager a pollution reduction credit, thereby allowing the $\mathrm{P}$ load reductions to occur on the farm. The value of the credit has to be more than $\$ 20$ but less than $\$ 30$ for the system to produce a net economic gain. For the sake of the example, let us say that the LF sells one credit to the MWTP for $\$ 25$. Table 2 summarizes the trading transaction. The same environmental goal of reducing phosphorus by two units is achieved but at a lower total cost of $\$ 40$. Both parties share a portion of the savings, which in this case is a lower cost of compliance by $\$ 5$ each.

\section{Elements of a WQCT Program WHAT GOAL ARE WE TRYING TO ACHIEVE?}

First, policy makers (with public input) must determine the environmental goal to be achieved within a basin (e.g., fish propagation, safety for recreation, etc.) and related criteria to judge the quality of water (such as concentration of nitrogen or oxygen dissolved in water). This goal and related criteria can allow assessing the maximum pollution loading from all sources that can be allowed in the basin (i.e., up to a certain level of pollution loading, basins have a capacity to cleanse themselves-assimilate pollution).

\section{WHO INFLUENCES WATER QUALITY IN THE BASIN?}

Industry, wastewater treatment plants, and agriculture typically represent major sources of water pollution. Wastewater treatment plants, industry, and some urban and agricultural sources that discharge through well-defined outflow points are called point sources. Point sources are regulated under the federal Clean Water Act, and permits are required for pollution emission referred to as National 
Pollution Discharge Elimination System (NPDES) permits. Pollution loading from such sources can be monitored or estimated based on the pollution abatement technology used.

Most agricultural and urban areas, however, contribute to water pollution through a diffuse runoff over land surface. These sources are called nonpoint sources. Because runoff from nonpoint sources is spread across areas like fields and pastures, actual pollution volume is difficult to measure. Nonpoint sources are not required to obtain any pollution permits, although in many Florida regions, agricultural BMP implementation is mandatory, and a Notice of Intent (NOI) to implement the BMPs should be submitted to the Florida Department of Agriculture and Consumer Services (Migliaccio et al. 2019; FDACS 2017; UF/IFAS 2017).

Pollution loading from nonpoint sources is usually difficult to monitor; however, computer models can be used to estimate their pollution contribution or its reduction due to BMP implementation. Experiments can also be used when BMPs are implemented in strictly controlled conditions such as well-defined and well-monitored parts of the basin, or on research farms.

In the Chesapeake Bay and other areas, there is currently a lot of interest in another strategy to reduce nutrient pollution concentration in water-through nutrient removal naturally occurring as part of shellfish production. Oysters and hard-shell clams can remove nutrients from water as they grow, which can potentially be used to offset pollution loading from various sources in the basin (Avilia et al. 2015; Baker et al. 2016; NCCOS 2017).

While pollution removal through shellfish production can potentially be an important player in the water quality credit market, the focus of many WQCT programs is to promote transactions between point and nonpoint sources. The costs of pollution abatement from nonpoint sources are usually lower than from point sources, and since the point sources are legally liable for pollution reduction under their NPDES permits, the regulatory pressure on point sources usually drives the trading. In such transactions, point sources are usually buying pollution reduction from nonpoint sources.

\section{WHAT IS THE BASELINE LEVEL OF POLLUTION?}

To sell pollution reduction, a source needs to reduce their pollution beyond some baseline level. A baseline is a reference level of pollution discharge. For point sources, this baseline level is level described in the NPDES permit.
For nonpoint sources, different WQCT programs develop baselines differently. For example, some programs use estimated load set for a specific point in time (e.g., in the year prior to the date when the WQCT program was established). Other programs describe specific sets of BMPs that should be implemented before participating in a WQCT program (practice-based baseline) (Shortle 2013). In Florida, practice-based baseline was discussed for agricultural producers, requiring them to implement relevant BMPs discussed in the Florida Department of Agriculture manuals (FDACS 2017).

\section{WHAT ARE POLLUTION REDUCTION CREDITS?}

Credits are units of goods (pollution reduction) to be traded. They are generated for every unit of pollution reduction below a baseline level. Credits should be accurately measured or estimated using a computer model.

\section{WHO ARE WILLING BUYERS AND SELLERS OF CREDITS?}

For sellers, it should be profitable to generate the credit and sell it on the water quality credit markets. For buyers, it should be more profitable to buy credits from the market than to abate pollution themselves. If the credit sellers are agricultural producers, they should also be willing to allow agencies or other independent organizations to verify the credit generated.

Note that WQCT focuses on a specific watershed. Unlike carbon credits for greenhouse gas emissions, a buyer of water quality credits must purchase credits for pollution reductions from the seller within the same watershed.

\section{HOW IS CREDIT PRICE DETERMINED?}

Credit price is usually determined from negotiations between buyer and seller. It is usually bounded from below by the costs of load reductions to the seller (e.g., BMP implementation cost), and from above by the cost of an abatement alternative for the buyer (e.g., installation and maintenance cost for an abatement technology).

\section{WHAT ARE TRADING RATIOS?}

A trading ratio is the number of load-reduction credits from one source that can be used to compensate excessive loads from another source. A delivery trading ratio is set to ensure that trading among distant sources (e.g., upstream and downstream) does not violate an overall watershed pollution cap. For example, if the delivery trading ratio for upstream and downstream sources is set to 2:1, the upstream source should generate two units of pollution reduction to offset one unit emitted by a downstream source. An 
uncertainty trading ratio specifies the number of pollution reduction credits generated by the nonpoint source that should be purchased by the point source to offset one unit of its own discharge. The ratio is set to account for seasonal and daily changes in nonpoint source loading, and can be set greater than, equal to, or less than one. For example, if the uncertainty trading ratio for municipal nonpoint sources and wastewater treatment plants is set to $3: 1$, the wastewater treatment plant would need to purchase three units of pollution reduction from the municipal nonpoint source to offset one unit of its own emission.

\section{IS THERE A ROLE FOR GOVERNMENT REGULATION?}

The regulatory agency plays an important role in a WQCT program. It determines the water quality goals, establishes a cap for pollutants in a watershed, approves and administers the trading program, and monitors and enforces the trading rules. For a WQCT program to be successful, the state agencies must be willing to assume additional economic and regulatory responsibility associated with this innovative policy tool.

\section{WQCT in Watersheds}

Based on US Environmental Protection Agency (US EPA) data (2016b), water quality trading will not work everywhere. Trading works best when

1. There is a regulatory driver that motivates sources to seek pollution reductions. Such regulatory driver can be a Total Maximum Daily Load (TMDL) or a more stringent pollution discharge requirement in the National Pollution Discharge Elimination System (NPDES) permits held by point sources.

\section{Pollution reduction requirements faced by some sources} do not exhaust all the pollution reduction options available. In other words, the baseline load for nonpoint sources should be high enough to allow the sources to generate pollution reduction credits by reducing loads beyond the baseline. Similarly, to encourage credit supply by municipal or industrial point sources, emission levels allowed through NPDES should be high enough to leave the sources with the opportunity to reduce emissions beyond permit requirements and therefore generate credits. If this condition is not satisfied, there may not be enough surplus reductions to generate market activities.

3. Various sources within the watershed have significantly different costs to reduce pollutants of concern. In this case, there will be willing buyers and sellers in the water quality credit market. Additionally, the difference should be significant enough to cover transaction costs between trading partners (i.e., the costs of finding the trading partner and negotiating the trading agreement).

4. Watershed stakeholders and the state regulatory agency are willing to try an innovative approach and allow for adjustments in trading design and implementation as the market evolves with new buyers and sellers.

\section{Challenges Facing a WQCT Program}

There are challenges associated with almost every essential element of the WQCT program. It is difficult to link public water quality goals (such as fish restoration) with the amount of pollution that can be discharged into the water body by all sources in the watershed. Furthermore, it is challenging to establish the baseline load for agricultural and urban nonpoint sources. Nonpoint pollution is spread over large areas and varies by site-specific factors and weather events. It is difficult to establish the baseline limit for nonpoint source pollution (since their loading cannot be easily measured or estimated).

Baselines also raise the question of responsibility for pollution cleanup, property rights of landowners, and fairness. A liberal baseline that allows nonpoint sources to contribute a significant pollution load to a water body would not improve impaired waterbodies (of assessed waterbodies, about $54 \%$ of miles in streams and rivers, $80 \%$ of acres in lakes, and $72 \%$ of springs are impaired (FDEP 2016)). In turn, a stringent baseline would not allow nonpoint sources to participate in trading since no pollution reductions would be possible below the baseline. Establishing a baseline equal to the current estimated pollution load would disadvantage agricultural producers who have previously implemented best management practices to reduce their pollution runoff.

Similar to the challenges of establishing a pollution baseline, it is difficult to measure pollution reduction (i.e., verify credits) which leads to uncertainty about the magnitude of water quality improvement from a trade. The effectiveness of a BMP depends on site-specific conditions, BMP age, implementation, and maintenance. Scientific models used to estimate load reduction from BMPs are imperfect, and the estimated reductions from a BMP will likely differ from actual loadings. There is also ongoing debate about whether credits generated from BMPs installed using public (costshare) funds should be eligible for trades.

There can be significant transaction costs associated with WQCT. Examples of transaction costs include the efforts 
associated with locating buyers and sellers and the costs of negotiating the agreement. Transaction costs are almost always higher when a nonpoint source is involved in trading because of the complexity of measuring and verifying credits generated by the nonpoint source. Nonpoint sources often offer only a few credits so that the point source buyer must find and negotiate trades with multiple nonpoint sources to acquire sufficient credits. Methods to lower these transaction costs include (1) setting up a credit bank or a clearinghouse that can simplify the process of searching for the trading partner, (2) developing a standardized language in regulatory compliance documents, and (3) using model contracts for sales.

Industrial and municipal point sources are legally liable for achieving contractual pollution reductions via NPDES permits. In contrast, most agricultural and urban nonpoint sources do not have such permits. Therefore the only document binding nonpoint sources in the transaction is the contract with point sources. This makes the point source (the buyer) responsible for enforcing the contract. Many point sources would rather reduce their liability and pay for expensive upgrades that are under their control than leave themselves dependent on the performance of a third party from whom they have purchased credits. Some mechanisms to address this liability issue include (1) a marketable insurance fund or program to back up the credits; (2) regulated credit trading banks that guarantee credit availability over a 20- to 30-year period at a fixed cost; and (3) private unregulated aggregators and private entities that purchase credits for the purpose of re-sale to interested buyers (aggregators generally purchase large quantities of credits from nonpoint sources, and they are usually able to accept and manage the risks inherent in the water quality market).

\section{Conclusions}

Public policy goals such as improving water quality will impose costs on people and businesses within the watershed. A water quality credit trading system offers a way to minimize compliance costs across the region. This document reviews the basic components of a water quality credit trading program and discusses the opportunities and challenges associated with such a program.

\section{Additional Information}

You can learn more about WQCT from the following online resources:

- Chapter 403 of the Florida Statutes: A discussion of WQCT statewide as part of basin management action plans implementation (http://www.leg. state.fl.us/Statutes/index.cfm?App_mode=Display_ Statute\&URL=0400-0499/0403/Sections/0403.067.html)

- US EPA: A collection of documents describing the basics of WQCT, as well as the trading programs implemented in various US states (https://www.epa.gov/npdes/ water-quality-trading)

- USDA / Office of Chief Economist: A collection of resources related to water quality trading programs (https:// www.nal.usda.gov/legacy/waic/water-quality-trading)

- Market Watch: A review of WQCT programs and other programs offering payments for providing water-related ecosystems services (such as pollution reduction) developed by Ecosystem Marketplace (http://www.ecosystemmarketplace.com/marketwatch/water/)

\section{Acknowledgment}

The content of this publication is largely based on Abdalla et al. (2007). We appreciate the helpful feedback for this publication by Dr. Fritz Roka, formerly associate professor in the University of Florida/IFAS Food and Resource Economics Department at Southwest Florida Research and Education Center in Immokalee, Florida, who is now Director of the Center for Agribusiness at Florida Gulf Coast University, Ft. Myers, Florida.

\section{References}

Abdalla, C., T. Borisova, D. Parker, and K. Saacke Blunk. 2007. Water quality credit trading and agriculture: Recognizing the challenges and policy issues ahead. Choices 22(2). http://www.choicesmagazine.org/2007-2/index.htm

Avila, J., K. Grogan, and S. Larkin. 2015. Estimating the Value of Ecosystem Services Generated by the Hard Clam Industry in Florida. Project Report, Food and Resource Economics Department, University of Florida. http:// shellfish.ifas.ufl.edu/wp-content/uploads/valuationsummary-083115.pdf

Baker, S., K. Grogan, S. Larkin, and L. Sturmer. 2016. Environmental Benefits: "Green" Clams: Estimating the Value of Environmental Benefits (Ecosystem Services) Generated by the Hard Clam Aquaculture Industry in Florida. Gainesville, FL: University of Florida, IFAS. http://shellfish.ifas.ufl.edu/ environmental-benefits/ 
Bennett, G., N. Carroll, and K. Hamilton. 2013. Charting new waters: State of watershed payments 2012. Ecosystem Marketplace, January 17. http://www. ecosystemmarketplace.com/pages/dynamic/article.page. php?page_id=9542\&section $=$ news_articles\&eod $=1$

FDACS. 2021. Agricultural Best Management Practices. Tallahassee, FL: Florida Department of Agriculture and Consumer Services (FDACS). https://www.fdacs.gov/Agriculture-Industry/Water/ Agricultural-Best-Management-Practices

FDEP. 2016. Integrated Water Quality Assessment for Florida: 2016 Sections 303(d), 305(b), and 314 Report and Listing Update. Tallahassee, FL: Florida Department of Environmental Protection (FDEP). http://www.dep.state. fl.us/water/docs/2016-Integrated-Report.pdf

FDEP. 2021. Watershed Management: Basin Management Action Plans. Tallahassee, FL: Florida Department of Environmental Protection (FDEP). https:// floridadep.gov/dear/water-quality-restoration/content/ basin-management-action-plans-bmaps

Greenhalgh, S., and M. Selman. Comparing water quality trading programs: What lessons are there to learn? The Journal of Regional Analysis and Policy 42(2):104-125

McCann, L., B. Colby, K.W. Easter, A. Kasterine, and K.V. Kuperan. 2005. Transaction cost measurement for evaluating environmental policies. Ecological Economics 52:527-542.

Migliaccio, K.W., K.T. Morgan, B.J. Boman, S. Guzman, and H. Bayabil. 2019. Total Maximum Daily Loads and Agricultural BMPs in Florida. AE388. Gainesville, FL: University of Florida, Institute of Food and Agricultural Sciences. https:// edis.ifas.ufl.edu/AE388

NCCOS. 2017. Nutrient Crediting of Oyster Aquaculture in Chesapeake Bay. Silver Spring, MD: National Centers for Coastal Ocean Science (NCCOS). https:// coastalscience.noaa.gov/news/coastal-pollution/ nutrient-crediting-oyster-aquaculture-chesapeake-bay/

Selman M., E. Branosky, and C. Jones. 2009. Water Quality Trading Programs: An International Overview. Washington, DC: Water Resource Institute. http://www.wri.org/publication/ water-quality-trading-programs-international-overview
Shortle, J. 2013. Economics and environmental markets: Lessons from water-quality trading. Agricultural and Resource Economics Review 42(1):57-74.

UF/IFAS. 2017. Best Management Practices. Gainesville, FL: University of Florida, Institute of Food and Agricultural Sciences. http://bmp.ifas.ufl.edu/index.php

US EPA. 2017a. Clean Water Act Section 303(d): Impaired Waters and Total Maximum Daily Loads. Washington, DC: United States Environmental Protection Agency (US EPA). https://www.epa.gov/tmdl (accessed on June 14, 2017)

US EPA. 2017b. NPDES Wastewater and Stormwater Permits. Washington, DC: United States Environmental Protection Agency (US EPA). https://www.epa.gov/npdes-permits/ npdes-permits-epas-pacific-southwest-region-9

US EPA. 2017c. Polluted Runoff: Nonpoint Source Pollution. United States Environmental Protection Agency (US EPA), Washington, D.C. https://www.epa.gov/nps

US EPA. 2016a. Learn About Effluent Guidelines. Washington, DC: United States Environmental Protection Agency (US EPA). https://www.epa.gov/eg/ learn-about-effluent-guidelines

US EPA. 2016b. Water Quality Trading. Washington, DC: United States Environmental Protection Agency (US EPA). https://www.epa.gov/npdes/water-quality-trading

\section{Glossary}

Basin Management Action Plan (BMAP): BMAP summarizes pollution reduction strategies (such as permit limits on wastewater facilities, and urban and agricultural best management practices) for restoring impaired waters and meeting the allowable loadings established in a Total Maximum Daily Load (TMDL) (FDEP 2021).

Best Available Technology (BAT): Best Available Technology Economically Achievable (BAT) is "the best available economically achievable performance of plants" (US EPA 2016a). BAT is based on "the cost of achieving BAT effluent reductions; the age of the equipment and facilities involved; the process employed; ... non-water quality environmental impacts, including energy requirements; and other factors as the [US Environmental Protection Agency] EPA Administrator deems appropriate" (US EPA 2016a). 
Best Management Practice (BMP): Practical, cost-effective actions that agricultural producers can take to conserve water and reduce the amount of pesticides, fertilizers, animal waste, and other pollutants entering our water resources. BMPs are designed to benefit water quality and water conservation while maintaining or even enhancing agricultural production" (FDACS 2017).

\section{National Pollution Discharge Elimination System (NP-}

DES) permits: The National Pollutant Discharge Elimination System (NPDES) permit program controls water pollution by regulating point sources (i.e., sources that discharge through a pipe or a well-defined discharge point). "[I]ndustrial, municipal, and other facilities must obtain permits if their discharges go directly to surface waters. In most cases, the NPDES permit program is administered by authorized states" (US EPA 2017b).

Nonpoint Sources (NPS): NPS are diffuse sources, and NPS pollution is caused by rainfall or snowmelt moving over and through the ground. As the runoff moves, it picks up and carries away natural and human-made pollutants, finally depositing them into lakes, rivers, wetlands, coastal waters, and underground sources of drinking water. These pollutants include: excess fertilizers, herbicides, and insecticides from agricultural lands and residential areas; oil, grease, and toxic chemicals from urban runoff and energy production; sediment from improperly managed construction sites, crop and forest lands, and eroding stream banks; salt from irrigation practices and acid drainage from abandoned mines; bacteria and nutrients from livestock, pet wastes, and faulty septic systems; atmospheric deposition; and hydromodification (US EPA 2017c).

Point Sources: Point sources are discrete conveyances such as pipes or manmade ditches (US EPA 2017b).

Total Maximum Daily Load (TMDL): “A TMDL establishes the maximum amount of a pollutant allowed in a waterbody and serves as the starting point or planning tool for restoring water quality" (US EPA 2017a).

Transaction Costs: The costs of finding and contacting trading partner, negotiating and completing the trade, and monitoring end enforcing the contract. For in-depth discussion see McCann et al. (2005). 
Table 1. No trading allowed.

\section{Municipal Wastewater Treatment Plant (MWTP)}

$\$ 30$ to remove one unit of $P$ from the discharge using best available technology (BAT)

(BAT Example: An enhanced biological phosphorus removal system)

\section{Livestock Farmer (LF)}

$\$ 20$ to remove one unit of $P$ from the discharge using best management practices (BMP)

(BMP Example: Establish a forested riparian buffer adjacent to a stream)

Environmental Goal: Reduce P discharge into the water by two units. Since there is no trading, each entity must reduce its individual discharge by one unit.

Total cost to achieve environmental goal: $\$ 50=(\mathrm{MWTP})(1 \times \$ 30)+(\mathrm{LF})(1 \times \$ 20)$

Cost incurred by the sources:

MWTP: $\$ 30 \times 1$ unit $=\$ 30$

LF: $\$ 20 \times 1$ unit $=\$ 20$

Table 2. Trading allowed.

Municipal Wastewater Treatment Plant (MWTP)

$\$ 30$ to remove one unit of $\mathrm{P}$ from the discharge using best available technology (BAT)

LF sells one credit to MWPT for $\$ 25$ and reduces $P$ by two units.

Total cost to achieve environmental goal: $\$ 40=(L F)(2 \times \$ 20)$

Cost incurred by the sources:

MWTP: $\$ 30 \times 0$ unit $+\$ 25$ (credit price) $=\$ 25$

LF: $\$ 20 \times 2$ units $-\$ 25$ (credit price) $=\$ 15$

\section{Livestock Farmer (LF)}

$\$ 20$ to remove one unit of $P$ from the discharge using best management practices (BMP) 